\title{
Reconstruction of face and scalp after dog bites in children
}

\section{Reconstrução de face e couro cabeludo após mordeduras caninas em crianças}

Jefferson lessa Soares Macedo, TCBC-DF¹,2; Simone Corréa Rosa'; Murilo Neves de Queiroz²; Tabatha Gonçalves Andrade Castelo BRANCO GOMES².

\begin{abstract}
A B S T R A C T
Objective: to evaluate the immediate reconstruction of face and scalp after canine bites in children. Methods: we conducted a prospective series of cases treated at the Emergency Unit of the Asa Norte Regional Hospital, Brasilia - DF, from January 1999 to December 2014. At the time of patient admission to the emergency, the primary wound closure of the face and scalp bite was performed, regardless of the time or day of the event. The primary treatment of the bites was by means of direct suture, flaps rotation or grafting, depending on the type of wound and surgeon's decision. Results: the study comprised 146 children, with the zygomatic region and scalp being the main sites of head bites. All patients received surgical treatment within the first 24 hours after admission. There were no infectious complications in the cases studied. Conclusion: the findings suggest that the immediate closure of canine bites on the face and scalp in children is safe, even when carried out several hours after injury.
\end{abstract}

Keywords: Face. Scalp. Bites and Stings. Dogs. Child. Reconstructive Surgical Procedures.

\section{INTRODUCTION}

$\mathrm{B}$ ites are common injuries, usually seen in hospital emergencies, accounting for $0.3 \%$ to $1.1 \%$ of visits ${ }^{1}$. They represent a public health problem because, in addition to the threat to the physical integrity of people, canine bites can transmit rabies and cause serious infections. This fact has mobilized public opinion, politicians and health professionals to make changes in Brazilian legislation and campaigns to prevent and treat those injuries ${ }^{1,2}$.

It is estimated that $36.5 \%$ of American households own at least one dog and $30.4 \%$ have at least one $\mathrm{cat}^{3}$. In addition, an estimated 4.5 million bite victims occur annually in the United States ${ }^{3}$. Of these, 6000 to 13,000 patients per year require specialized treatment and hospitalization due to canine bites, with an annual average of 19 deaths, ranging from 11 to 33 deaths per year from 1979 to $2005^{4}$.

Children are the main victims of canine attacks, both in morbidity and lethality ${ }^{5}$. It is believed that half of the children were bitten by dogs at some stage of their lives, and one of the main injury sites in this age group is the head, which increases morbidity ${ }^{1}$. The usual recommended conduct is that wounds caused by bites should not be closed, and reconstruction delayed until after the period of greatest risk of infection has passed. However, in recent years, several authors have advocated the primary surgical treatment of canine bites that occur on the face and scalp ${ }^{6,7}$.

The objective of this study was to evaluate the immediate reconstruction of face and scalp after canine bite in children.

\section{METHODS}

The study was a prospective series of cases and comprised 146 patients who were initially treated at the Emergency Unit of the Plastic Surgery Service of the Asa Norte Regional Hospital (Brasília-DF) from January 1999 to December 2014. Patients were admitted to the study consecutively. Exclusion criteria were: patients who already had signs of infection at the bite site on admission; Patients with an outpatient follow-up of less than 30 days; and patients aged 13 or over.

1 - Asa Norte Regional Hospital (HRAN), Plastic Surgery Service, Brasilia, Distrito Federal, Brazil. 2 - Superior School of Health Sciences, Medicine School, Brasilia, Distrito Federal, Brazil. 
Table 1. Distribution of children victims of dog bites in the face and scalp, attended at the HRAN, Brasilia, DF, according to the time elapsed from the event, to the site of injury and to the type of treatment.

\begin{tabular}{lcc}
\hline & Number of patients & $\%$ \\
\hline Time from event & 91 & 62.3 \\
$<6$ hours & 40 & 27.4 \\
6 to 24 hours & 15 & 10.3 \\
$>24$ hours & & \\
Site of injury & 44 & 30.1 \\
Zygomatic & 39 & 26.7 \\
Scalp & 21 & 14.4 \\
Front & 15 & 10.3 \\
Nose & 13 & 8.9 \\
Lip & 9 & 6.2 \\
Ears & 5 & 3.4 \\
Eyelids & & \\
Treatment & 102 & 69.8 \\
Suture & 38 & 26.1 \\
Grafting & 6 & 4.1 \\
Local flap rotation & & \\
\hline
\end{tabular}

Data were collected through a questionnaire with the patient or legal guardian. The variables analyzed were: age, gender, origin, time interval of the event to hospital care, aggressor agent, place of injury, characteristics of the lesions and treatment. The postoperative follow-up was done through weekly consultations for at least 30 days. The sutures were removed between the seventh and tenth postoperative days.

The conduct in cases of bite on the face and scalp was copious irrigation of the wound and cleaning with $1 \%$ polyvinylpyrrolidone degermant solution (PVPI) or 2\% chlorhexidine and saline solution. The primary closure on the arrival day was done by means of direct suture, local flap rotation or grafting. There was no limit of hours or days between the time of the event and the surgical procedure, that is, when the patient arrived at the hospital emergency room, the procedure was performed regardless of the time or day of the event. The devitalized tissues were debrided and there was no sign of wound infection at the time of closure. In cases of lesions near the main parotid duct or the tear duct, the integrity of these structures was evaluated and repair was performed, when necessary.

Tetanus and rabies prophylaxis were performed as appropriate. All study patients received antimicrobials during seven days. The antibiotic of choice was a 1st generation cephalosporin (cephalexin)

The work was approved by the Ethics in Research Committee of the State Health Department of the Federal District, under CAAE number 52737216.2 .0000 .5553$.

\section{RESULTS}

The study comprised 146 children, with a mean age of seven years (ranging from 1 to 12). The majority of the patients were male (60.3\%) and 105 (70.9\%) were from the Federal District. Children who were nine years of age or less were the main victims, representing $79.4 \%$ of the sample. Regarding the time of care, 91 (62.3\%) patients were seen in the first six hours after the accident (Table 1). 


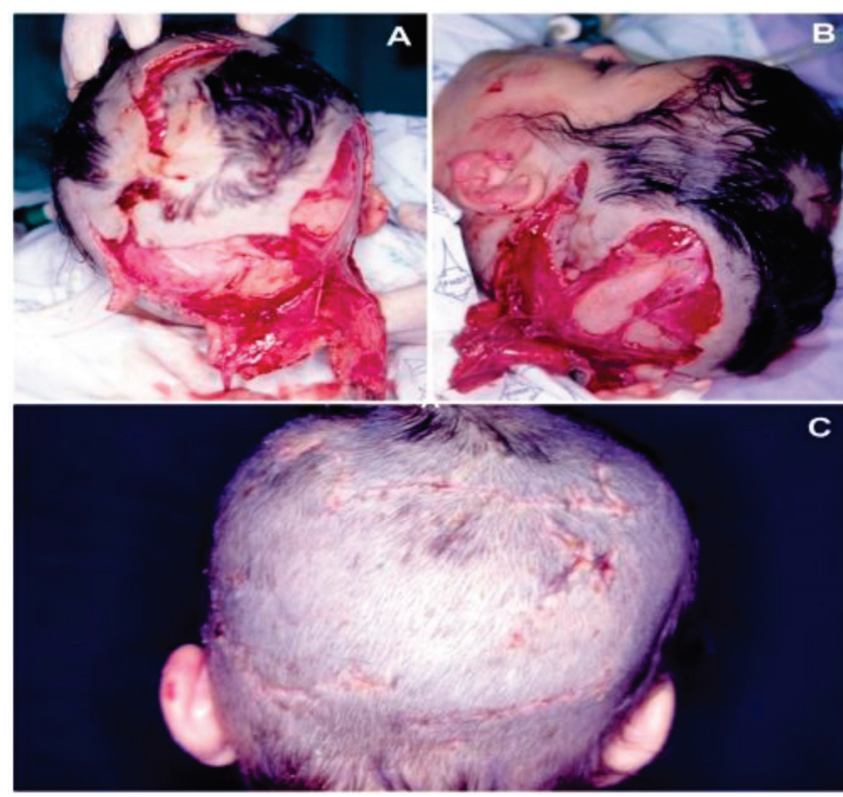

Figure 1. A and B) Child with extensive scalp lesion due to canine bite, without loss of substance, subjected to the immediate closure; C) Postoperative 2-month evolution.

The zygomatic region was the main site of bites on the face in children, followed by the scalp (Figures 1 and 2). No wound showed signs of infection on admission. All patients received surgical treatment within the first 24 hours after hospital admission.

Regarding the severity of the lesions, 44 (30.1\%) patients presented loss of substance. There were two cases of bone fracture in the face and skull. One of the patients had extensive scalp lesions associated with fractures of the occipital, temporal and zygomatic bones, and underwent neurosurgical and soft tissue treatment (Figure 2).

The most common type of treatment was direct suture in 102 (69.8\%) cases, followed by skin grafting $(26.1 \%)$ or local flap rotation $(4.1 \%)$. The type of anesthesia most used was general due to the fact that they were children with extensive lesions. There was no case of human or animal rabies, neither deaths nor infections in the study (Figure 3 and 4).

\section{DISCUSSION}

Canine attacks to children are an important cause of morbidity and, to a lesser extent, lethality, accounting for 80 to $90 \%$ of all bites seen in emergency units $^{1}$. It is estimated that the rate of canine bite care in American emergencies is 1.3 per 1000 inhabitants, leading to 44,000 canine bite injuries annually ${ }^{8}$. However, this rate is less than realistic, with only $36 \%$ of canine bites being treated in the hospitals or informed to authorities 8,9 .

Children are the most affected, as $26 \%$ of childhood bites require medical care, compared to $12 \%$ in adults. Children are the main fatal victims of canine attacks, since $80 \%$ of canine bites in children occur in the head and neck, whereas this region is affected in adults in less than $10 \%$ of cases $^{5}$. The high prevalence of head bites in children is attributed to the short stature and increased face exposure associated with the spontaneity of bringing the face close to the dogs $9,10,11$. In most cases, attacks involve familiar or family dogs, usually away from the physical presence of an adult, and there is no specific breed of dog that is more involved in the attacks $2,4,12$.

A complete clinical examination is essential, associated with a detailed examination of the wound under general anesthesia, as appropriate. Especially in children, there is a possibility of associated lesions

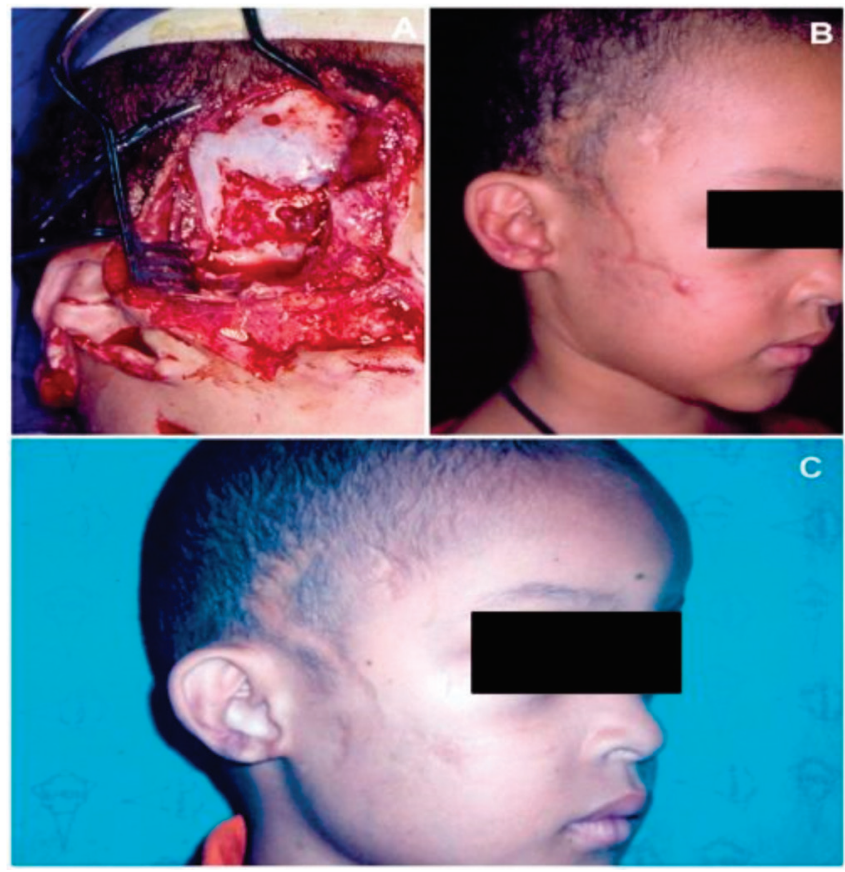

Figure 2. A) A five years old child with temporal bone fracture due to canine bite, submitted to neurosurgical treatment and immediate closure of the lesions on the face; $B$ ) Postoperative 2-month evolution; C) Postoperative 1-year evolution. 


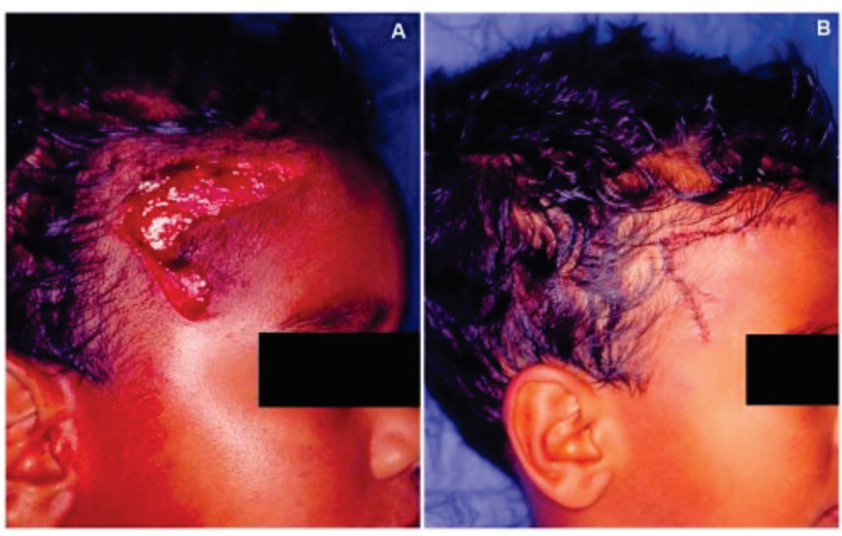

Figure 3. A four years old child victim of canine bite on the face and scalp, submitted to immediate lesion suture; B) postoperative 7-day evolution.

such as airways, cervical spine, vessels, nerves, eyeball, lacrimal apparatus, cranial and facial fractures, which should be remembered and investigated ${ }^{13,14}$. In our study, there was a child with multiple cranial and facial fractures, requiring neurosurgical intervention during the repair of facial and scalp lesions.

The most common site of canine head attacks in children was the zygomatic region. Other studies point to the lip or ear as the most frequent site but those are series that also involve adults 2,15 .

The antibiotics of choice after bites on the face and scalp is amoxicillin with clavulanic acid or cephalexin (1st generation cephalosporin). The use of the culture to choose the antibiotic is only done in cases where the infection is already established, streptococci and staphylococci being the most frequent germs ${ }^{7}$. In canine attacks, prophylaxis of tetanus and rabies are mandatory ${ }^{16}$.

The primary treatment of bites was by means of direct suture, grafting or local flaps, depending on the type of wound and the surgeon's decision, regardless of the time elapsed from the attack. It is important to properly debride the wound and minimize the use of deep or subdermal sutures. Whenever possible, sutured wounds are managed without closed dressing ${ }^{13}$. Direct suture was the treatment of choice in most patients, but in cases of avulsion of part of the scalp, the avulsed segment was grafted (Figure 4). Subsequently, after integration of the graft, the surgeon can initiate the expansion of the remaining scalp to cover the graft alopecia area.

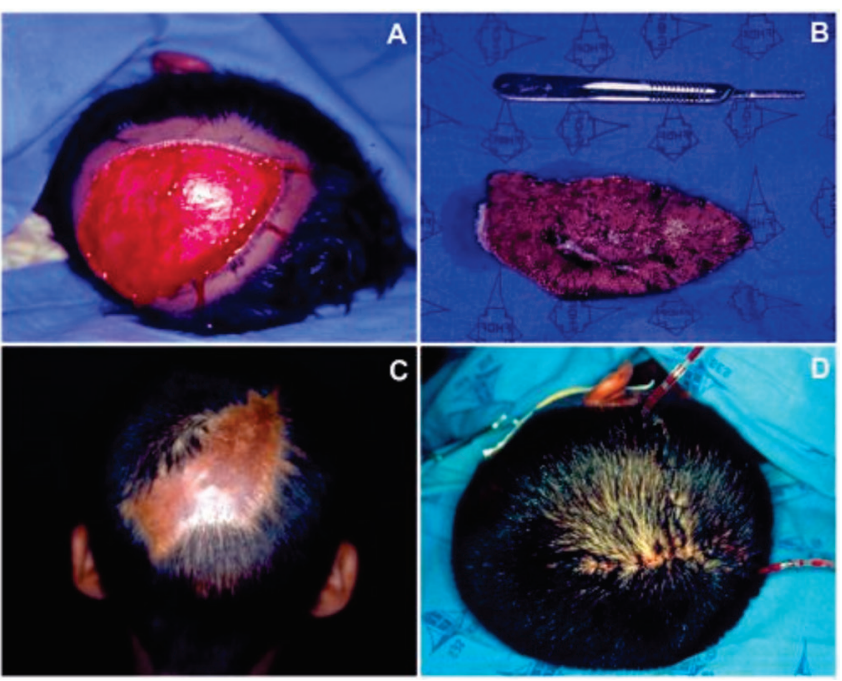

Figure 4. A six years old child with partial avulsion of the scalp by canine bite, submitted to immediate grafting of the avulsed segment. After six months of grafting, she was submitted to resection of the grafted area with alopecia (A, B and C) and direct closure of the scalp (D).

Primary suture of lesions have advantages over delayed closure. Open lesions require daily dressings and high doses of analgesics during and after dressings changing. These disadvantages are avoided by immediate surgical repair, and the aesthetic damage is handled 13,17-19.

Post-bite recommendations, with or without surgical treatment, should include a description for patients and their caregivers of signs and symptoms of infection, indicating immediate reassessment in the event of such signs. Except for trivial cases, all victims of bites should be re-evaluated within 48 hours $^{3}$.

Wound infection is the most common complication after bites. The probability of infection is influenced by several factors, such as the aggressor animal, the location of the wound, factors inherent to the individual, the characteristics of the lesions and the time elapsed until medical care².

The etiological agents most frequently isolated from infected bite wounds are those of the oral flora of the offending animal or the victim's skin. In canine bites, the most isolated aerobic microorganisms are staphylococci, Pasteurella spp. (Mainly P. canis and Pasteurella multocida), streptococci, Neisseria spp. and Corynebacterium spp. Among the anaerobes, Fusobacterium, Porphyromonas, Prevotella, Propionibacterium, Bacteroides and Peptostreptococus stand out. 
Punctate bites, hand bites, human bites, lesions longer than eight hours and wounds in immunocompromised patients (patients with diabetes mellitus or systemic lupus erythematosus, chronic renal failure, splenectomy, prolonged us e of corticosteroids) are at increased risk of infection. Considering that the study cases involved only canine bites in immunocompetent patients, these factors may have contributed to the non-existence of infection in the analyzed population. In addition, bites on the face and scalp have a lower chance of infection than elsewhere in the body due to the rich vascularization and postural drainage of this body segment ${ }^{20}$.

In minor infected wounds, oral amoxicillin with clavulanate ensures excellent coverage for infected bites by dogs, cats or humans. In cases of allergy to penicillin, clindamycin may be used. In more sever infections, the treatment should be intravenous, with the use of ampicillin with sulbactan. In cases of infection with methicillin- or oxacillin-resistant S. aureus (MRSA or ORSA), the association with vancomycin is recommended ${ }^{3}$.
There have been reports of disseminated infections, septic shock, meningitis and endocarditis after bites by dogs and cats. The etiological agents most involved in these types of infectious complications are Capnocytophaga canimorsus and Pasterurella multocida ${ }^{21}$.

One should give special attention to sepsis by Capnocytophaga canimorsus in cases of febrile illness after canine bites, especially in patients with prior splenectomy or chronic alcoholism. Cases of severe systemic infections are more common after bites on the hands or fingers, and rarely after bites on the head ${ }^{21-23}$.

Our work demonstrates that face and scalp lesions produced by canine bites can be repaired primarily. With this approach, a better aesthetic result is achieved with minimal or no risk of infection, reducing subsequent surgical procedures and improving morbidity. The primary closure of these lesions can be done through direct suture, local flap rotation or grafting, depending on the type of wound and the surgeon's decision.

\title{
RE S U M O
}

\begin{abstract}
Objetivo: avaliar a conduta de reconstrução imediata de face e couro cabeludo após mordedura canina em crianças. Métodos: série prospectiva de casos atendidos na Unidade de Emergência do Hospital Regional da Asa Norte, Brasília/DF, no período de janeiro de 1999 até dezembro de 2014. No momento da admissão do paciente à emergência, foi realizado o fechamento primário da ferida proveniente de mordedura em face e couro cabeludo, independente da hora ou dia da agressão. O tratamento primário das mordeduras foi realizado por meio de sutura direta, retalhos ou enxerto, conforme o tipo da ferida e da decisão do cirurgião. Resultados: o estudo compreendeu 146 crianças, sendo que a região zigomática e o couro cabeludo foram os principais sítios das mordeduras na cabeça. Todos os pacientes receberam tratamento cirúrgico dentro das primeiras 24 horas após a admissão. Não houve complicações infecciosas nos casos estudados. Conclusão: os achados sugerem que o fechamento imediato das mordeduras caninas em face e couro cabeludo em crianças é seguro, mesmo quando realizado várias horas após a lesão.
\end{abstract}

Descritores: Face. Couro Cabeludo. Mordeduras e Picadas. Cães. Criança. Procedimentos Cirúrgicos Reconstrutivos.

\section{REFERENCES}

1. Weiss HB, Friedman DI, Coben JH. Incidence of dog bite injuries treated in emergency departments. JAMA. 1998;279(1):51-3.

2. Macedo JLS, Camargo LM, Almeida PF. Estudo prospectivo do fechamento primário das mordeduras caninas e humanas na face e no couro cabeludo. Rev Soc Bras Cir Plást. 2006;21(1):23-9.

3. Ward MA. Bite wound infections. Clin Pediatr
Emerg Med. 2013;14(2):88-94.

4. Langley RL. Human fatalities resulting from dog attacks in the United States, 1979-2005. Wilderness Environ Med. 2009;20(1):19-25.

5. Sacks JJ, Lockwood R, Hornreich J, Sattin RW. Fatal dog attacks, 1989-1994. Pediatrics. 1996; 9(6 Pt 1):891-5

6. Mcheik JN, Vergnes P, Bondonny JM. Treatment of facial dog injuries in children: a retrospective study. J Pediatr Surg. 2000;35(4):580-3. 
7. Fleisher GR. The management of bite wounds. N Engl J Med. 1999; 340(2):138-40.

8. Chang YF, McMahon JE, Hennnon DL, LaPorte RE, Coben JH. Dog bite incidence in the city of Pittsburgh: a capture-recapture approach. Am J Public Health. 1997;87(10):1703-5.

9. Rosado B, García-Belenguer S, Léon M, Palacio J. A comprehensive study of dog bites in Spain, 19952004. Vet J. 2009;179(3):383-91. Eub 2008 Apr 10.

10. Mitchell RB, Nañez G, Wagner JD, Kelly J. Dog bites of the scalp, face, and neck in children. Laryngoscope. 2003;113(3):492-5.

11. Lee $Y G$, Jeong $S H$, Kim WK. An analytical study of Mammalian bite wounds requiring inpatient management. Arch Plast Surg. 2013;40(6):70510. Epub 2013 Nov 8.

12. Cruz GAO. Sutura primária no tratamento de mordedura canina: avalição de resultados. Rev Méd Paraná. 2003;61(1):8-11.

13. Macedo JLS, Rosa SC. Reconstrução de couro cabeludo após mordedura canina. Rev Col Bras Cir. 2004;31(1):27-33.

14. Varela JE, Dolich MO, Fernandez LA, Kane A, Henry R, Livingston J, et al. Combined carotid artery injury and laryngeal fracture secondary to dog bite: case report. Am Surg. 2000;66(11):1016-9.

15. Donkor P, Bankas DO. A study of primary closure of human bite injuries to the face. J Oral Maxillofac Surg. 1997;55(5):479-81; discussion 481-2.

16. Brasil. Ministério da Saúde. Secretaria de Vigilância em Saúde. Departamento de Vigilância Epidemiológica. Normas técnicas de profilaxia da raiva humana. Brasília (DF): Ministério da Saúde; 2011.

17. Low DW. Modified chondrocutaneous advance- ment flap for ear reconstruction. Plast Reconstr Surg. 1998;102(1):174-7.

18. Franciosi LFN, Weber ES, Righesso R, Pizzoni VRS, Molon MP, Piccoli MC. Reparação do escalpo por retalhos livres microcirúrgicos. Rev Bras Cir Plást. 2010;25(4):624-9.

19. Talan DA, Citron DM, Abrahamian FM. Bacteriologic analysis of infected dog and cat bites. Emergency Medicine Animal Bite Infection Study Group. N Engl J Med. 1999;340(2):85-92.

20. Stefanopoulos PK, Tarantzopoulou AD. Facial bite wounds: management update. Int J Oral Maxilofac Surg. 2005;34(5):464-72.

21. Oehler RL, Velez AP, Mizrachi M, Lamarche J, Gompf S. Bite-related and septic syndromes caused by cats and dogs. Lancet Infect Dis. 2009;9(7):439-47. Erratum in: Lancet Infect Dis. 2009;9(9):536.

22. Ong YS, Levin LS. Hand infections. Plast Reconstr Surg. 2009;124(4):225e-233e.

23. Pers C, Gahrn-Hansen B, Frederiksen W. Capnocytophaga canimorsus septicemia in Denmark, 1982-1995: review of 39 cases. Clin Infect Dis. 1996, 23(1):71-5.

Received in: 11/08/2016

Accepted for publication: 01/10/2016

Conflict of interest: none.

Source of funding: none.

\section{Mailing address:}

Jefferson Lessa Soares Macedo

E-mail: jlsmacedo@yahoo.com.br scrmacedo@yahoo.com.br 